\title{
Comentário: Ocidente/Oriente
}

\author{
Sabrina Areco $^{1}$
}

Referência do texto comentado: COSTA, Daniel Padilha Pacheco da. Houellebecq contra Michel Foucault: representações contemporâneas do Islã político na França. Trans/Form/Açáo: revista de filosofia da Unesp, vol. 43, n. 4, p. $147-172,2020$.

O artigo "Michel Houellebecq contra Michel Foucault: Representações contemporâneas do Islã político na França” explora a leitura dos dois intelectuais acerca do Islã, mais precisamente sobre o chamado Islã político. O tema tem como plano de fundo diferentes momentos da elaboração daquilo que E. Said chamou de Orientalismo, isto é, a construção de uma visão acerca do Oriente como forma de definir náo apenas o Outro, mas o próprio Ocidente.

Tratam-se de registros do pensamento político, em formatos diversos, ou seja, a produçáo filosófica de Foucault e a literatura de Houellebecq, e de leituras acerca do Islã colocadas em circulação nos ambientes intelectuais e políticos franceses da segunda metade do século XX - início do século XXI. Longe de serem homogêneas, as elaboraçóes sobre o tema são objeto de fortes debates e controvérsias, das quais as produçóes de Houellebecq e de Foucault são parte. Constituem, portanto, manifestaçôes do pensamento político e seus autores são artífices e componentes do cenário indicado, ao mesmo tempo em que produziram em momentos históricos diversos.

Michel Houellebecq é um mestre da provocação, o que certamente contribui para a difusão de seus livros. O lançamento Submission (2015) foi

\footnotetext{
${ }^{1}$ Doutora em Ciência Política (UNICAMP), filiada à ABCP - Centro Norte e membro da IGS-Brasil (International Gramsci Society). (iD https://orcid.org/0000-0003-1853-0037. E-mail: sabrinaareco@ gmail.com. Campinas, São Paulo. Brasil.
}

http://dx.doi.org/10.1590/0101-3173.2020.v43n4.10.p179

This is an open-access article distributed under the terms of the Creative Commons Attribution License. 
seguido de ampla repercussão midiática e a importância da persona polêmica do autor permite ver certa subversão na própria ideia de recepção de uma obra como algo a posteriori ao seu lançamento. A repercussão do livro foi produto da escolha de um material altamente inflamável naquele país: certa exotização do Oriente, o suposto "risco" de islamização da França e a misoginia do personagem. Se partimos da concepçáo de Moretti (2003) acerca da existência de uma geografia do romance, podemos considerar a produção de Houellebecq como uma das possíveis representaçóes do terreno francês contemporâneo, com as clivagens que lhes são internas.

Como o artigo indica, há em Submission a presença das ideias de R. Camus a respeito da Grande Substituição. Camus identifica a existência de um movimento de islamizaçáo e de troca, inclusive demográfica, do suposto "povo tradicional" francês por árabes muçulmanos. Uma parte significativa dos debates identitários da extrema-direita francesa apoia-se nessa formulação. $\mathrm{O}$ autor do artigo também identificou Foucault como um interlocutor de Houellebecq, nesse caso, como um contraponto. Costa sugere que a conversão ao islamismo pelo acadêmico François, personagem do livro, seria uma crítica à suposta defesa do Islã político por Foucault e da continuidade de tal posição existente em parte da esquerda francesa: "Levando adiante sua crítica sistemática, iniciada em Les particules élémentares (1998), à French Theory, Houellebecq denuncia o filósofo francês e seus herdeiros ideológicos como colaboracionistas com a Grande Substituiçãa”".

A proposição é interessante. Em entrevistas, Houellebecq apontou M. Foucault como a grande referência dos movimentos de esquerda franceses herdeiros de 1968 e da forma como estes lidam com a religiosidade muçulmana. Costa indica a atenção do romancista pelo filósofo e desperta a curiosidade do leitor de conhecer essa relação, de maneira mais direta e concreta. Foucault tratou do Islã e sua política em textos sobre a Revolução Iraniana, que são basicamente reportagens e entrevistas. Alguns são do ano de 1979, por isso, refletem vivamente as impressóes sobre a Revoluçáo, tendo retomado o assunto posteriormente. É importante demarcar a temporalidade dessas reflexões, sob o risco de considerá-las como dotadas de absoluta coesão, quando, em realidade partem da análise de dois momentos bastante distintos da política no Irã.

Em suas primeiras manifestações sobre a Revolução Iraniana, o filósofo pós-estruturalista identificava na oposição ao Xá Reza Shah Pahlavi e nas tendências que afirmavam a necessidade de um regime islâmico como uma 
crítica à Ocidentalização, ou mesmo uma reação política à Modernização, queencontrava na espiritualidade e ritos islâmicos sua forma. Por isso, poderiam ser vistas como uma maneira particular e não ocidental de fazer política. O mundo moderno e laico havia separado as dimensôes espiritual e política e imposto ao mundo árabe, que estaria, para Foucault, em plena resposta a tal imposição.

Mais tarde, Foucault lembra que, como intelectual, lhe cabia o lugar de espectador e não julgar a Revolução em razão de suas finalidades, mas antes valorizar todas as formas de reação ao poder. Por isso, Costa aponta que, para Foucault, tratava-se de "valorizar a experiência revolucionária ela mesma", e não o Irã ou o Islã, e, "embora não a abandone, a ideia de revolução é submetida a uma completa reformulação, fundada na ética”. Porém, não era possível dissociar o conteúdo das revoltas - a defesa de um governo islâmico - de uma visão positiva da Revolução Iraniana. Isto é, tratava-se não de tomar uma defesa da revolta em abstrato, mas antes de analisar as condiçóes particulares daquela revolta. Isso era claro para alguns analistas políticos do período e para pessoas implicadas naqueles movimentos - como para as mulheres iranianas, que passaram a ser ameaçadas pela não observância de regras religiosas impostas a elas, como o uso do véu. Observava-se a insurgência dos iranianos e, ainda que o retorno ao sagrado não fosse defendido por ele, era isso que ocorria antes mesmo da chegada de Khomeini ao poder.

Com quem Foucault dialogava, quando tratou do Irã, no início da Revolução? Em parte com a França, em parte, com a Itália (onde parte dos artigos foi publicado) e também com a população do próprio país do chamado Oriente Médio - convulsionado, depois da crise do petróleo, e em meio aos esforços das potências estrangeiras, entre elas, EUA e França, em encontrar um ponto de apoio naquela parte do mundo. E o aiatolá Khomeini era então saudado por essas potências como capaz de ser o pacificador aliado. $\mathrm{O}$ que veio depois no Irã foi a criação de uma teocracia, com perseguição aos dissidentes e supressão de direitos, que serviu de fundamento para a Guerra com o Iraque, conduzida por Saddam Hussein, de novo apoiado pelos EUA.

Temos, portanto, dois elementos aqui a serem considerados. Primeiro, é preciso olhar as reflexóes de Foucault 1979 e as posteriores ao desfecho da Revolução Iraniana, sendo muito cuidadoso em relação aos dois contextos. Para além da temporalidade dos textos, o segundo ponto seria identificá-los como escritos circunstanciais. As reflexôes sobre o Irã poderiam ser vistas tanto as reportagens como as entrevistas - como análises de conjuntura política. 
E as manifestaçóes públicas de Foucault, depois de 1979, parecem antes tentativas de justificar aquelas emitidas anteriormente. Logo, também a reação dos críticos e a recepção nos ambientes intelectuais e políticos nos ajudam a entender as posiçóes assumidas pelo autor de Vigiar e punir, especialmente se considerarmos o período posterior à chegada de Khomeini ao poder.

No romance de Houellebecq, por sua vez, há a passagem para um regime guiado pela sharia, a lei islâmica, mas na França. A política conduzida no país sob o regime islâmico teria resolvido a crise social e econômica que o país atravessava. E François converte-se ao Islã, depois de um cálculo oportunista. Assim, podemos pensar que nem a conversão do personagem François nem a existência de um governo islâmico na França marcam propriamente a submissáo ao Outro, ao Oriente muçulmano. O governo islâmico seria justamente a resolução da crise no Ocidente com a subsunção do Oriente. E é expressivo que o elemento que encadeia as mudanças no governo francês diga respeito ao lugar da mulher. As mulheres, que François já tratava como subalternas. $\mathrm{O}$ que isso indicaria? Que há pontos de contatos entre as duas culturas?

Esses elementos surgiram da leitura do artigo de Costa, os quais são trazidos aqui como comentários bastante gerais, mas fortemente articulados com o esforço - que entendo também ser o do autor do artigo - de abordar a política em diferentes formas de registro e de capturar as diversas elaboraçóes acerca do Oriente.

\section{REFERÊNCIAS}

FOUCAULT, M. O enigma da revolta: entrevistas inéditas sobre a Revolução Iraniana. São Paulo: N-1, 2018.

HOUELLEBECQ, Michel. Submissão. Tradução de Rosa Freire d'Aguiar. Rio de Janeiro: Objetiva, 2015.

MORETTI, F. Atlas do romance europeu: 1880-1900. São Paulo: Boitempo, 2018.

Recebido: $20 / 10 / 2020$

Aceito: 26/10/2020 